Review

\title{
ANIMAL-BASED AGRICULTURE, PHOSPHORUS MANAGEMENT AND WATER QUALITY IN BRAZIL: OPTIONS FOR THE FUTURE
}

\author{
Francirose Shigaki ${ }^{1}$; Andrew Sharpley ${ }^{2 *}$; Luís Ignácio Prochnow ${ }^{1}$

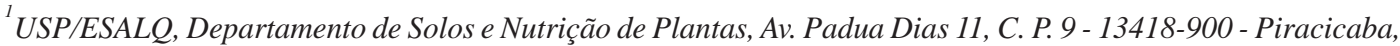 \\ SP. - Brasil. \\ ${ }^{2}$ U.S. Department of Agriculture, Agricultural Research Service, Pasture Systems and Watershed Management \\ Research Unit, Building 3702, Curtin Road, University Park, PA, U.S.A., 16802 \\ *Corresponding author 〈andrew.sharpley@ars.usda.gov>
}

\begin{abstract}
Eutrophication has become a major threat to water quality in the U.S., Europe, and Australasia. In most cases, freshwater eutrophication is accelerated by increased inputs of phosphorus $(\mathrm{P})$, of which agricultural runoff is now a major contributor, due to intensification of crop and animal production systems since the early 1990s'. Once little information is available on the impacts of Brazilian agriculture in water quality, recent changes in crop and animal production systems in Brazil were evaluated in the context of probable implications of the fate of $\mathrm{P}$ in agriculture. Between 1993 and 2003, there was 33\% increase in the number of housed animals (i.e., beef, dairy cows, swine, and poultry), most in the South Region (i.e., Paraná, Rio Grande do Sul, and Santa Catarina States), where 43 and $49 \%$ of Brazil's swine and poultry production is located, respectively. Although grazing-based beef production is the major animal production system in Brazil, it is an extensive system, where manure is deposited over grazed pastures; confined swine and poultry are intensive systems, producing large amounts of manure in small areas, which can be considered a manageable resource. This discussion will focus on swine and poultry farming. Based on average swine $(100 \mathrm{~kg})$ and poultry weights $(1.3 \mathrm{~kg})$, daily manure production $(4.90$ and $0.055 \mathrm{~kg}$ per swine and poultry animal unit, respectively), and manure $P$ content ( 40 and $24 \mathrm{~g} \mathrm{~kg}^{-1}$ for swine and poultry, respectively), an estimated 2.5 million tones of $\mathrm{P}$ in swine and poultry manure were produced in 2003. Mostly in the South and Southeast regions of Brazil (62\%), which represent only $18 \%$ of the country's land area. In the context of crop P requirements, there was 2.6 times more P produced in manure (1.08 million tones) than applied as fertilizer (0.42 million tonnes) in South Brazil in 2003. If it is assumed that fertilizer P use represents $\mathrm{P}$ added to meet crop needs and accounts for P sorbed by soil in unavailable forms each year, if swine and poultry manure were to replace fertilizer, there would be an annual P surplus of 0.66 million tonnes in the South region alone. These approximations and estimates highlight that, similarly to other parts of the world, there is a potential for surplus $\mathrm{P}$ to quickly accumulate in certain regions of Brazil. Unless measures are developed and implemented to utilize manure P, repeated annual surpluses will create an increasingly difficult problem to solve. These measures can be grouped as source and transport management. Source management attempts to decrease dietary P, use feed additives, manure treatment and composting, as well as careful management of the rate, timing, and method of manure applications. Transport management attempts to control the loss of $\mathrm{P}$ in runoff from soil to sensitive waters via use of conservation tillage, buffer or riparian zones, cover crops, and trapping ponds or wetlands. These measures are discussed in the contest of Brazil's climate, topography, and land use, and how successful remediation programs may be implemented at farm and watershed level.
\end{abstract}

Key words: diffuse pollution, eutrophication, poultry production, swine production, surface runoff

\section{PRODUÇÃO ANIMAL, MANEJO DE FÓSFORO E QUALIDADE DA ÁGUA NO BRASIL: OPÇÕES PARA O FUTURO}

RESUMO: Eutrofização dos mananciais de água se tornou uma preocupação nos Estados Unidos, Europa e Austrália. Na maioria dos casos, a eutrofização de mananciais de água é acelerada pelo aumento na quantidade de fósforo adicionada, o que tem estreita relação com o escorrimento superficial deste elemento, em função da intensificação dos sistemas de produção de culturas e animais a partir do início dos anos noventa. Em virtude de pouca informação com relação aos impactos da agricultura na qualidade da água, este artigo enfatiza modificações nos sistemas de produção de culturas e animais no Brasil no contexto das 
prováveis implicações quanto ao destino do fósforo no processo. Os dados apontam para um aumento de 33\% no número de animais (gado de corte, gado de leite, suíno e frango) no período de 1993 - 2003, a maior parte deste aumento ocorrendo na região sul (Paraná, Rio Grande do Sul e Santa Catarina), onde se localizam $43 \%$ e $49 \%$ da produção de suínos e frangos, respectivamente. Enquanto a produção de gado de corte se dá predominantemente em sistema de pastejo a campo, com deposição do esterco sobre os pastos, a produção de suíno e frango ocorre em sistema intensivo de confinamento, o que resulta em elevadas quantidades de esterco em pequenas áreas. Assim sendo, a discussão irá focalizar na produção de suínos e frangos. Tendo em vista o peso médio de suíno $(100 \mathrm{~kg})$ e frango $(1,3 \mathrm{~kg})$, a produção diária de esterco $(4,90$ e $0,055 \mathrm{~kg}$ por suíno ou frango, respectivamente), e o conteúdo médio de $\mathrm{P}$ no esterco (40 e $24 \mathrm{~g} \mathrm{~kg}^{-1} \mathrm{para}$ suíno e frango, respectivamente), estimou-se uma quantidade de 2,5 milhões de toneladas de fósforo nos estercos de suíno e frango, produzidas no Brasil em 2003. A maior parte foi produzida nas regiões sul e sudeste do Brasil (62\% em conjunto), a qual representa apenas $18 \%$ da área do país. No contexto da exigência das culturas, os cálculos apontam para 2,6 vezes mais fósforo produzido nos estercos $(1,08$ milhões de toneladas) do que aplicado por meio de fertilizante ( 0,42 milhões de toneladas) na região sul em 2003. Diante do fato que a quantidade utilizada por fertilizantes representa o necessário para atender as exigências nutricionais das plantas, levando inclusive em consideração o fósforo adsorvido pelo solo, se o esterco de suíno e frango fosse considerado no sentido de substituir os fertilizantes aplicados, haveria uma sobra anual de 0,66 milhões de toneladas apenas na região sul. Estas aproximações e estimativas claramente indicam que, como em outras partes do mundo, existe potencial para esta sobra anual de fósforo rapidamente acumular em certas regiões do Brasil. A menos que medidas sejam desenvolvidas e implementadas para utilizar este esterco, repetidas sobras anuais irão conduzir a um problema de difícil resolução. Estas medidas podem ser agrupadas em dois tipos: as do manejo das fontes e as do transporte. As medidas que visam o manejo das fontes tendem a diminuir as quantidades de fósforo na dieta, usar aditivos no alimento, promover o tratamento e compostagem do esterco, bem como manejar com cuidado as doses, época, e método de aplicação dos estercos. As medidas visando o manejo no transporte objetivam controlar a perda de fósforo no escorrimento do solo para os corpos de água por meio da conservação do solo e resíduos, zonas vegetativas ribeirinhas de contenção, culturas de cobertura superficial, e pontes de aprisionamento ou áreas alagadas. Estas medidas são discutidas no contexto do clima, topografia, uso do solo, e ainda quanto ao sucesso dos programas de remediação a serem implementados em fazendas ou bacias hidrográficas.

Palavras-chave: eutrofização, fonte de poluição difusa, medidas corretivas, produção de aves, produção de suínos

\section{INTRODUCTION}

Recent assessments of water quality status have identified eutrophication as one of the most ubiquitous water quality impairments in the U.S., Europe, and Australasia (Heaney et al., 2001; New Zealand, 1997; U. S. Geological Survey, 1999). Eutrophication is the natural aging of lakes or streams brought on by nutrient enrichment. This process can be greatly accelerated by human activities which increase nutrient loading rates to water. While both phosphorus $(\mathrm{P})$ and nitrogen $(\mathrm{N})$ contribute to eutrophication, $\mathrm{P}$ is the primary agent in freshwater eutrophication, as many algae are able to obtain $\mathrm{N}$ from the atmosphere (Schindler, 1977). Thus, controlling eutrophication mainly requires reducing $\mathrm{P}$ inputs to surface waters, despite the fact that $\mathrm{P}$ is an essential nutrient for crop and animal production.

Eutrophication restricts water use for fisheries, recreation, and industry due to the increased growth of undesirable algae and aquatic weeds and oxygen shortages caused by their death and decomposition. Also, an increasing number of surface waters have ex- perienced periodic and massive harmful algal blooms (e.g., cyanobacteria and Pfiesteria), which contribute, along other things, to summer fish kills, unpalatability of drinking water, formation of carcinogens during water chlorination, and links to neurological impairment in humans (Burkholder \& Glasgow Jr., 1997; Howarth et al., 2000).

Although concern over eutrophication is not new, there has been a profound shift in our understanding of, and focus on, sources of $\mathrm{P}$ in water bodies. Since the late 1960s, the relative contributions of $\mathrm{P}$ to water bodies, both from point and diffuse sources, have changed dramatically. On one hand, great strides have been made in the control of point source discharges of $\mathrm{P}$, such as the reduction of $\mathrm{P}$ in sewage treatment plant effluent. These improvements have been due, in part, to the ease in identifying point sources. On the other hand, less attention has been directed to controlling diffuse sources of $\mathrm{P}$, due mainly to the difficulty in their identification and control (Sharpley \& Rekolainen, 1997). Thus, control of diffuse sources of $P$ is a major hurdle to protecting fresh surface waters from eutrophication (Sharpley \& Tunney, 2000; Withers et al., 2000). 
While a variety of diffuse sources, ranging from suburban to construction areas, contribute $\mathrm{P}$ to water bodies, agriculture, particularly intensive animal agriculture, is receiving more research, public, and regulatory attention (Kellogg et al., 2000; Sharpley, 2000; U.S. Environmental Protection Agency, 2004). There is, however, no information on the role of agricultural management on $\mathrm{P}$ loss as related to water quality impairment in Brazil.

The aim of this paper is to (1) show how agricultural production systems in Brazil have changed over the last decade in ways that have increased the potential for $\mathrm{P}$ loss in runoff, (2) present research on factors controlling $\mathrm{P}$ loss from agricultural land to water, and (3) show how this information can be used to develop agricultural management strategies that minimize the potential for P loss from Brazilian agricultural systems. For this discussion, information will be present on the basis of the five regions of Brazil; North, Northeast, Central-west, Southeast, and South (Figure 1).

\section{EVOLUTION OF AGRICULTURAL PRODUC- TION SYSTEMS IN BRAZIL}

Growth of Animal-Based Agriculture - An increasing world population that demands high qual- ity protein and fiber production at a low cost has resulted in an intensification of agricultural production systems. Brazil is no exception, with annual population growth of $1.65 \%$, the country expects to have a population of 257 million in 2030 . However, the country does have the potential to increase crop and animal production for internal consumption as well as export. For example, with a diversified climate, regular rainfall, abundant solar energy, and almost $13 \%$ of the world's potable water, Brazil has 300 million hectares of highly productive, cultivated lands (Figure 1). There is an additional 90 million hectares of fertile lands that have not yet been brought into production (Brasil, 2004). Currently, Brazil is one of the world leaders in the export of a range of crop (coffee, sugar cane, alcohol, tobacco, and juice fruits) and animal produce (beef meat, hen meat, and leather).

To meet these needs there have been tremendous changes and growth of agricultural production systems in most developed countries, with crop and animal operations evolving into spatially-separated production systems (Evans et al., 1996; Lander et al., 1998). For animal agriculture, this change has involved an increase in the size of production units, greater reliance on technology, a corresponding decrease in human labor, increased confinement of animals, and a

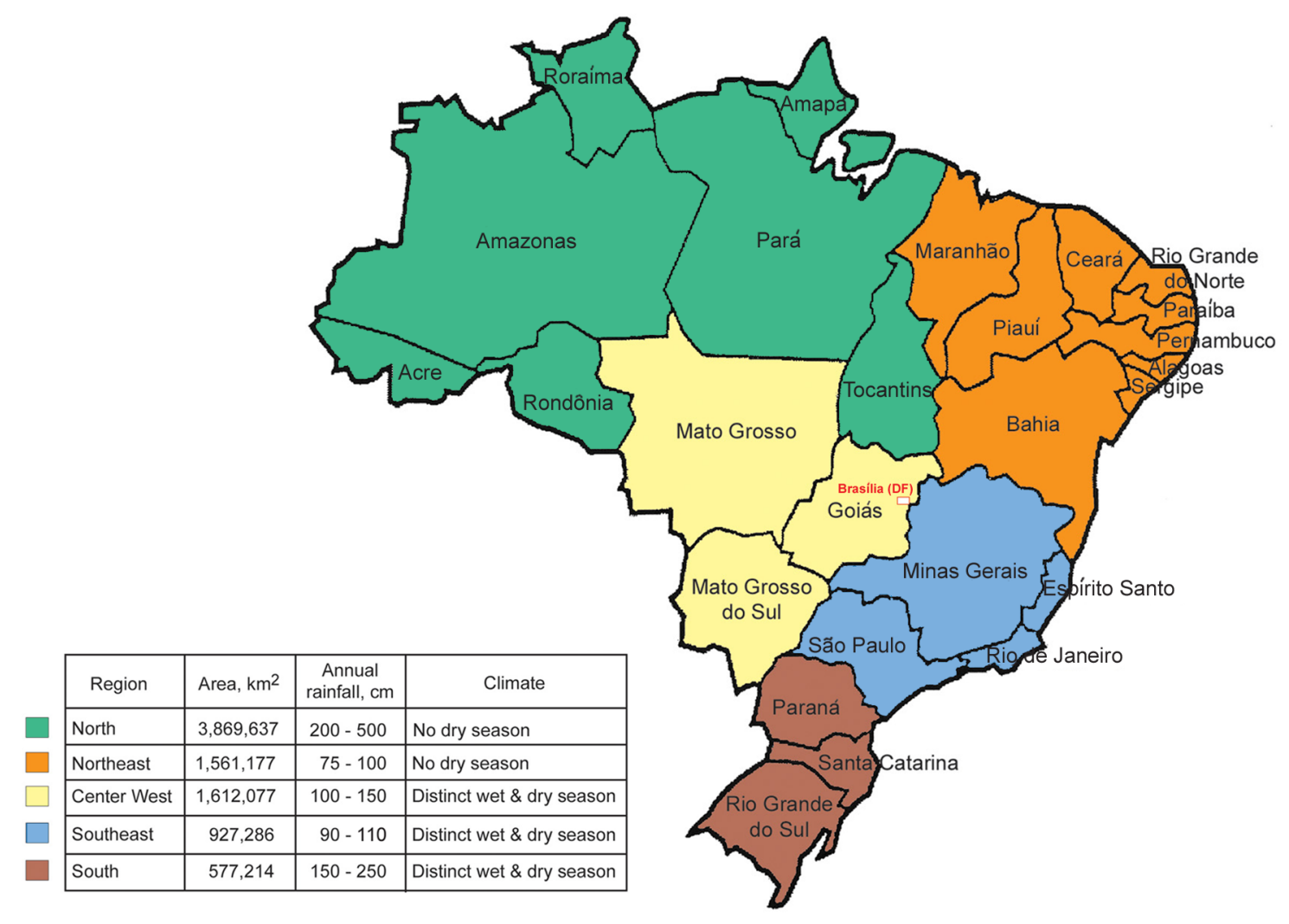

Figure 1 - The regions, area, and general climate of Brazil. Adapted from FAO (2005). 
general trend towards monoculture or specialized production systems (Hogberg et al., 2005). In the U.S. for instance, beef, dairy, pig, and poultry numbers have increased 10 to $30 \%$ since 1990 , while the number of farms on which they are reared has decreased 40 to $70 \%$ (Gardner, 1998). This intensification has been driven by a greater demand for animal products and improved profitability (Lanyon, 2000).

In the 1990's, there was a similar growth in the number of animal production systems in certain regions of Brazil. In fact, between 1993 and 2003, there was a $33 \%$ increase in the total number of animals in Brazil (Figure 2) (Instituto Brasileiro de Geografia e Estatística - Brazilian Geography and Statistics Institute, 2003). Most of this increase occurred in South Brazil (Figure 1), where 43 and $49 \%$ of the country's swine and poultry production is located. Although beef comprise the largest animal heard in Brazil (196 million head), their manure is not a manageable nutrientrich resource as is swine and poultry manure. While grazing-based beef production is an extensive system where the manure is deposited over grazed pastures, confined or housed swine and poultry are intensive systems, producing large amounts of manure in localized areas (Seganfredo, 2000; Miranda et al., 1999). The large increase in size and number of animal production systems leads to an overall increase in the potential for environmental impacts, because of the major input of nutrients in animal feed from grain-producing areas, which create localized surpluses of nutrient rich manure (Cromwell, 2005; Patterson et al., 2005). The following discussion will, therefore, be limited to management of manure from swine and poultry production systems, and which conservation or best management practices are available to minimize the potential for nutrient losses from land to water.

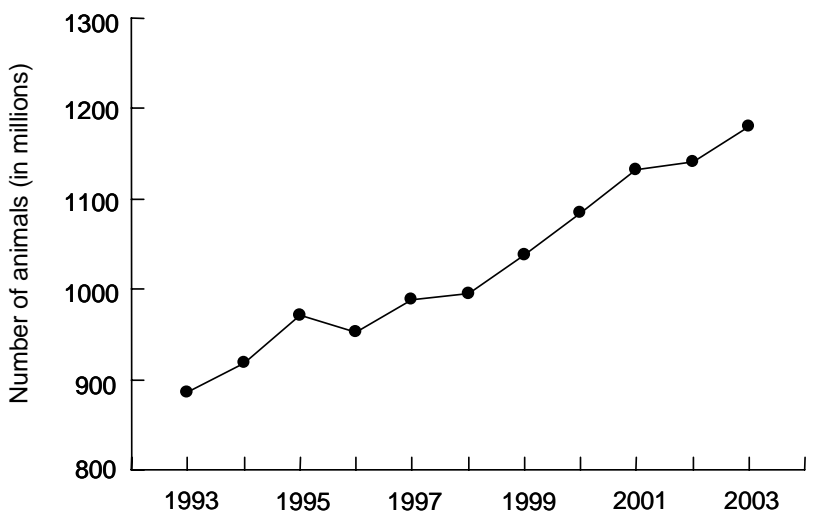

Figure 2 - The number of animals in Brazil; includes beef, goat, horses, poultry, and swine. Source: Instituto Brasileiro de Geografia e Estatistica (Brazilian Geography and Statistics Institute, 2003).
Manure Production and Phosphorus - Using estimates of the number of animals in Brazil from the recent national survey reported by the Instituto Brasileiro de Geografia e Estatistica (IBGE, 2003), we calculated the amounts of manure produced from representative average swine and poultry weights and excreta production (Table 1). An average animal weight of $100 \mathrm{~kg}$ for swine (Diesel et al., 2002) and $1.3 \mathrm{~kg}$ for poultry (Kellogg et al., 2000) was used. Daily production of $4.9 \mathrm{~kg}$ manure by each pig and $0.055 \mathrm{~kg}$ for each poultry bird was obtained from surveys conducted by Diesel et al. (2002) and Kellogg et al. (2000). Finally, chemical analysis of representative manures by Konzen (2003a) showed the concentration of total $\mathrm{P}$ in manure to average 40 and $24 \mathrm{~g} \mathrm{P} \mathrm{kg}^{-1}$ of swine and poultry manure, respectively (Table 1 ).

Clearly, animal weight, manure production, and $\mathrm{P}$ content of manure will vary greatly with animals' age, diet, and species. The concentration of $\mathrm{P}$ in manure is also influenced by manure treatment in the housing facility (e.g., amount of wash water and spillage from drinking troughs) and as well as subsequent manure storage and solid liquid separation, which will be discussed in a later section. However, the values of average animal weight, manure produced, and $\mathrm{P}$ concentration of manure that are presented in Table 1 and used to estimate regional manure $\mathrm{P}$ balances, are very similar to values for other parts of the world, as reported by Beegle (2002), Cromwell (2005), Patterson et al. (2005), and Kleinman et al. (2005). For instance, Sharpley \& Moyer (2000) found total P concentration averaged $32 \mathrm{~g} \mathrm{P} \mathrm{kg}^{-1}$ for swine manure (ranging from 23 to $39 \mathrm{~g} \mathrm{P} \mathrm{kg}^{-1}$ ) and $28 \mathrm{~g} \mathrm{P} \mathrm{kg}^{-1}$ for poultry manure

Table 1 - Swine and poultry numbers, weights, manure production and $\mathrm{P}$ content used to determine agricultural $\mathrm{P}$ budgets for regions in Brazil.

\begin{tabular}{|c|c|c|}
\hline Variable & Swine & Poultry \\
\hline Average weight, $\mathrm{kg}^{\dagger}$ & 100 & 1.3 \\
\hline Life cycle, days & 365 & 180 \\
\hline \multicolumn{3}{|l|}{ Manure produced } \\
\hline $\mathrm{kg}$ manure per $1000 \mathrm{~kg}$ animal ${ }^{-1} \mathrm{day}^{-1}$ & 49 & 36 \\
\hline $\mathrm{kg}$ manure animal ${ }^{-1}$ day $^{-1}$ & 4.90 & 0.055 \\
\hline Manure dry matter, \% & 10 & 35 \\
\hline Manure total $\mathrm{P}, \mathrm{g} \mathrm{P} \mathrm{kg}$ manure $^{-1 \S}$ & 40 & 24 \\
\hline Manure $\mathrm{P}$ produced, kg P animal ${ }^{-1}$ year $^{-1}$ & 72 & 0.24 \\
\hline \multicolumn{3}{|c|}{$\begin{array}{l}\dagger \text { Average weight for breeding stock and meat production pigs } \\
\text { and for broiler and laying poultry from Diesel (2002) and Kellogg } \\
\text { et al. (2000), respectively. } ¥ \text { Number of days in a year animal } \\
\text { produces manure. } \llbracket \text { Manure production per unit weight of swine } \\
\text { from Diesel (2002) and poultry from Kellogg et al. (2000). } \\
\S \text { Manure composition from Konzen (2003a). }\end{array}$} \\
\hline
\end{tabular}


(ranging from 20 to $36 \mathrm{~g} \mathrm{P} \mathrm{kg}^{-1}$ ). The similarity of manure production and composition estimates from Brazil in Table 1 and estimates from other parts of the world, lends support and credibility to the calculated amounts of $\mathrm{P}$ in manure on a regional basis using Table 1 values.

Based on the number of swine and poultry animals in 2003 (IBGE, 2003), a total of 65 million tonnes of swine and poultry manure was estimated as being produced in Brazil. The South and Southeast regions (40 million tonnes) accounted for $62 \%$ of the national total. For the whole country, there was an estimated 2.49 million tonnes of $\mathrm{P}$ in swine and poultry manure produced (Figure 3). On a regional basis, it can be seen from this figure that most of the swine and poultry manure $\mathrm{P}$ is produced in the South $(1.08$ million tonnes of $\mathrm{P})$ and Southeast regions of Brazil (0.45 million tonnes of P), which are both of smaller area $(577,214$ and $927,286 \mathrm{~km}^{2}$, respectively) than the other regions (North, 3,869,637 km² ; Northeast, 1,561,177 $\mathrm{km}^{2}$; and Center-west, 1,612,077 km²; Figure1).

To put this accumulation of $\mathrm{P}$ in swine and poultry manure into perspective in terms of annual crop production and $\mathrm{P}$ requirements, we compared manure $\mathrm{P}$ with fertilizer $\mathrm{P}$ use on farmed lands in Brazil (Figure 3). The amount of fertilizer applied in the production of a wide range of commercial crops in 2003 was obtained from POTAFOS (2005). For the whole country, there was 1.67 times more $P$ produced annually in swine and poultry manure (2.49 million tonnes) than used as fertilizer (1.49 million tonnes) (Figure 3). On a regional basis, only Center-west used more fertilizer $\mathrm{P}$ in 2003 than was produced in swine and poultry manure. In the South region, 2.6 times more $\mathrm{P}$ was produced annually as manure (1.08 million tonnes) than used as fertilizer ( 0.42 million tonnes). If the $\mathrm{P}$ used in fertilizer was replaced by swine and poultry manure, the large surplus of $\mathrm{P}$ is clearly of environmental sig-

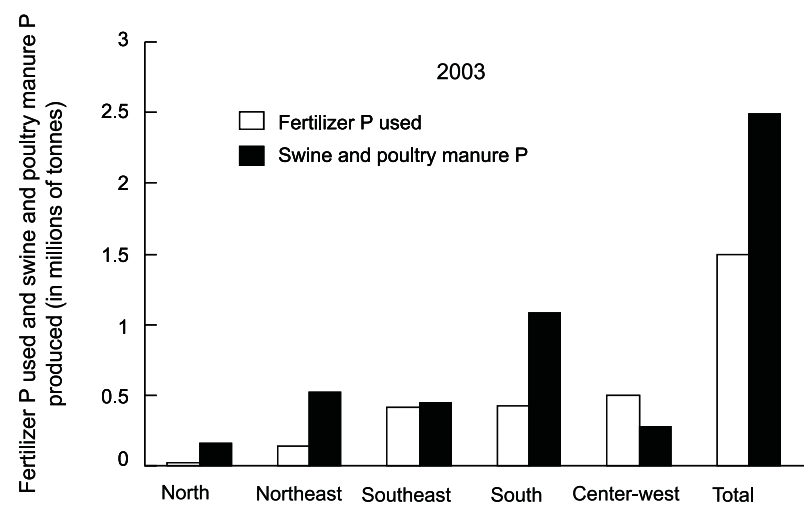

Figure 3 - The amount of fertilizer $\mathrm{P}$ used and $\mathrm{P}$ produced in swine and poultry manure in Brazil by region for 2003. Fertilizer use data adapted from Potafos (2005). nificance. Assuming that fertilizer $\mathrm{P}$ use represents that being added at optimal rates to meet crop needs and account for $\mathrm{P}$ sorbed by soil in forms unavailable for crop uptake, production of swine and poultry manure creates an annual surplus of 0.66 million tonnes of $\mathrm{P}$ in the South region of Brazil alone. Even if fertilizer $\mathrm{P}$ use, underestimates crop P requirements by $20 \%$, there will be 0.56 million tonnes of surplus manure $\mathrm{P}$ annually in the South and Southeast.

We have made these calculations and presented these approximations to highlight the fact that, as in the U.S. and Europe, there is a potential for $\mathrm{P}$ to quickly accumulate to levels that are much greater than crop needs in certain regions of Brazil. Unless measures are developed and implemented to utilize manures and $\mathrm{P}$ as soon as possible, repeated annual surpluses will create an increasingly difficult problem to solve. Again, we have focused on swine and poultry operations, because the manure produced is concentrated by animal confinement and is thus, a manageable resource.

Utilization of Manure in Agricultural Systems - As animals inefficiently utilize $\mathrm{P}$ in feed (only $30 \%$ is retained), most of the $\mathrm{P}$ entering animal operations ends up in manure, which is usually applied to land very close to where the manure is produced. Given the high nutrient and organic matter content of manure, when land applied it can be a valuable resource for improving soil structure and increasing vegetative cover, thereby reducing surface runoff and erosion potential. However, swine and poultry farms in the Southeast and South regions of Brazil are typically small farms, where production of manure $\mathrm{P}$ is much greater than the capacity to utilize this $\mathrm{P}$ on the farm (Oliveira, 2004). Further, these small farms do not have the necessary infrastructure to store, treat, or redistribute the manure. This leads to a rapid accumulation of $\mathrm{P}$ on the farm to levels that are well in excess of the crop requirements of the farm or even the region (Kellogg et al., 2000; Lander et al., 1998). Also, manure is often applied at rates designed to meet crop $\mathrm{N}$ requirements. This often results in a build up of soil test $\mathrm{P}$ above amounts sufficient for optimal crop yields, which can increase the potential for P loss in surface and subsurface runoff (Hart et al., 2004; Haygarth et al., 1998; Withers \& Lord, 2002).

Although the high price of mineral fertilizers in the past few years has been stimulating farmers to better utilize manure, there is a lack of technical and economic support so that this can be realistically achieved (Nones et al., 2002; Seganfredo, 2001a). Currently, therefore, the pollution potential of manure is not usually converted to productivity (Hoffmann et al., 2001; Vieira et al., 2002). 
In the U.S., this has led the Environmental Protection Agency (EPA) and the Department of Agriculture (USDA) to devise a joint strategy for sustainable nutrient management for concentrated animal feedings operations (U.S. Department of Agriculture \& Environmental Protection Agency, 1999). This strategy proposed a variety of voluntary and regulatory approaches, whereby all farms develop and implement a nutrient management plan, an important part of which outlines how acceptable application rates of $\mathrm{P}$ as mineral fertilizer or manure will be determined. In many countries, agencies charged with developing these strategies have challenged the scientific community to provide technical leadership in determining how and where $\mathrm{P}$ loss occurs and agricultural management options to decrease the loss.

In the U.S. and most European countries, legislation has been enacted to require farmers to implement management plans that provide for the sustainable use of manure nutrient and which protect the environment (U.S. Environmental Protection Agency, 2000; 2004). Only recently, however, has the Brazilian Government begun to look at developing nutrient and manure management guidelines, adoption incentives, and noncompliance penalties that address both agronomic production and environmental quality issues (Diesel et al., 2002).

Agronomic Response - Phosphorus applications in Brazilian crop production systems are based on the amount of plant-available soil P, as estimated from response curves that consider the best rate for agronomic effectiveness for each level of soil P (very low, low, medium, high or very high), as measured by recommended soil test $\mathrm{P}$ methods (most commonly resin or Mehlich-1 methods).

Early research in Brazil on the agronomic value of swine manure investigated native pasture production as influenced by swine manure application by Federal University of Santa Maria, Rio Grande do Sul, during 1998 and 1999 (Konzen, 2003b). When swine manure was applied to native grass pasture at a rate of $20 \mathrm{~m}^{3} \mathrm{ha}^{-1}$, dry-matter production increased between 21 to $204 \%$ compared to untreated pastures. At a manure application of $40 \mathrm{~m}^{3} \mathrm{ha}^{-1}$, there was a range in drymatter increase of 32 to $307 \%$ (Konzen, 2003b). Similar increases in dry-matter yields (156\%) of Brachiaria brizantha $\mathrm{cv}$. Marandu were also observed compared with the control (without fertilization) following different rates of swine manure application at the Federal University of Goias (Barnabe, 2001).

Swine manure application can also benefit pasture productivity for grazing cattle. For instance, the productivity of 78 ha cultivated with Brachiaria brizantha $\mathrm{cv}$. Marandu following the application of 180 $\mathrm{m}^{3} \mathrm{ha}^{-1}$ of swine manure parceled in six annual applications for five years, was evaluated by Konzen (2003b) for a farm located in Rio Verde, Goias. It was found that after the $4^{\text {th }}$ year it was possible to maintain 3.8 animal units per hectare in intensive grazing system.

There is little information detailing the effects of manure application on soil properties undertaken in Brazil. For the beneficial effects of manure application on soil nutrient status, general fertility, and structure, readers are directed to the reviews of Mullins et al. (2005) and Sharpley et al. (1998). Vieira et al. (2000), evaluating the effect of successive application of liquid swine manure on the chemical properties of a soil under native grass pasture over four years, did observe 1.0 and $3.3 \%$ increase in total C $(0-20 \mathrm{~cm}$ depth) with respective 20 and $40 \mathrm{~m}^{3} \mathrm{ha}^{-1}$ manure applications.

Clearly, manure can be an important source of $\mathrm{P}$ to farmers when applications are based on agronomic response and crop yield goals. If carefully managed, manure can also be a valuable resource for improving soil structure and increasing vegetative cover, thereby improving water quality via reduced runoff and erosion potential. For example, McDowell \& McGregor (1984) found that the application of $\mathrm{P}\left(30 \mathrm{~kg} \mathrm{P} \mathrm{ha}^{-1}\right)$ decreased runoff $\mathrm{P}$ in no-till corn $\left(1.8 \mathrm{~kg} \mathrm{P} \mathrm{ha}^{-1} \mathrm{yr}^{-1}\right)$ in comparison to no $\mathrm{P}$ applied $\left(2.0 \mathrm{~kg} \mathrm{P} \mathrm{ha}^{-1} \mathrm{yr}^{-1}\right)$, due to increased soil cover resulting from added P. Also, dairy and poultry manure applications at low rates $(<50$ $\mathrm{kg} \mathrm{P} \mathrm{ha}^{-1}$ ) imparts physical benefits to surface soil, which decreased P loss potential (McDowell \& Sharpley, 2003).

Environmental Response - Animal manure is typically land-applied to supply nutrients for crop growth, but the ratio of $\mathrm{N}$ and $\mathrm{P}$ in manure (typically $4: 1$ ) is not balanced relative to crop needs of $\mathrm{N}$ and $\mathrm{P}$ (typically 8:1). Land application of manure to meet the $\mathrm{N}$ needs of the crop, resulting in the over application and accumulation of $\mathrm{P}$ in soils, and subsequently elevated concentrations of $\mathrm{P}$ in runoff is frequent (Sharpley, 1995). Historically, P contamination of surface water was thought to be associated primarily to erosion. As application of $\mathrm{P}$ in excess of crop requirements continues, however, soils become saturated and runoff of $\mathrm{P}$ can occur independently of erosion (Carpenter et al., 1998; Daniel et al., 1998; Seganfredo, 2001b).

The ultimate goal of agricultural and environmental P management is to balance P inputs to the farm with outputs in primary produce, so that no excess $\mathrm{P}$ is applied and soil $\mathrm{P}$ concentrations are kept at an optimum level for agronomic performance and minimal 
environmental impact. However, when manure and nutrient applications are based on environmental rather than agronomic response, there is potential for major changes in agricultural management and negative economic impacts; it is thus necessary to explore shortterm or temporary fixes.

One of the critical, unresolved issues with manure utilization is the definition of the amount of manure that can be applied to a specific crop to meet expected yield goals. Agronomic recommendations for $\mathrm{P}$ applications are reliably made based on soil test $\mathrm{P}$, using regionally adopted methods and soil and crop type. However, there is little information on which to base manure application if environmental response is the primary concern (Seganfredo, 2001b).

Basically, two factors exacerbate the potential for environmental degradation from intensive swine and poultry production in Brazil. Firstly, these farms are concentrated in the strategically important Parana and Uruguai rivers basius, located in the relatively small Southern region (Oliveira, 2004). The potential for P-related water quality problems to occur in the Southeast and South regions of Brazil is aggravated by the fact that the region is typified by high rainfalls (90 to $250 \mathrm{~cm} \mathrm{yr}^{-1}$; Figure 1) and wavy landscapes. Secondly, these farms are comprised mainly of small rural producers that do not have the technical or financial support to introduce advanced manure treatment technology or conservation measures to minimize en- vironmental impacts. Thus, there is a need to set incentive programs for nutrient management by the combined efforts of the farming community, animal industry, and government to facilitate the environmentally sound use of $\mathrm{P}$ in manure, rather than treating it as a disposal problem. To put the situation into a different perspective, the pollutant capacity of swine manure is much greater than human waste. Using the concept of population equivalency, one swine produces the same amount of manure as 3.5 people (Diesel et al., 2002). Thus, a farm with 600 pigs produces the same amount of $\mathrm{P}$ in manure as a town of 2,100 people.

\section{FACTORS CONTROLLING P TRANSPORT IN RUNOFF}

The transport of $\mathrm{P}$ can occur by surface runoff and subsurface flow. In reality, these are very dynamic processes. For example, surface or overland flow can infiltrate into a soil during movement down a slope, move laterally as interflow, and reappear as surface flow. The main factors influencing the loss of $\mathrm{P}$ in both surface and subsurface runoff are summarized in Table 2.

The loss of $\mathrm{P}$ in agricultural runoff occurs in sediment-bound and dissolved forms (Figure 4). Sediment $\mathrm{P}$ includes $\mathrm{P}$ associated with soil particles and organic material eroded during flow events and constitutes $60-90 \%$ of $\mathrm{P}$ transported in surface runoff from most cultivated land (Carpenter et al., 1998; Sims \& Kleinman, 2005). Surface runoff from grass, forest, or

Table 2 - Factors influencing P loss from agricultural watersheds and its impact on water quality.

\begin{tabular}{|c|c|}
\hline Factors & Description \\
\hline \multicolumn{2}{|l|}{ Site Management } \\
\hline Soil P & As soil $\mathrm{P}$ increases, $\mathrm{P}$ loss in surface runoff and subsurface flow increases. \\
\hline Applied P & $\begin{array}{l}\text { The more } \mathrm{P} \text { applied (mineral fertilizer or manure), the greater the risk of } \mathrm{P} \\
\text { loss. }\end{array}$ \\
\hline Application method & $\begin{array}{l}\text { P loss increases in the order; subsurface injection, plowed under, and } \\
\text { surface broadcast with no incorporation. }\end{array}$ \\
\hline Application timing & The sooner it rains after $\mathrm{P}$ is applied, the greater the risk for $\mathrm{P}$ loss. \\
\hline P source & $\begin{array}{l}\text { The P in some fertilizers and manures is more soluble than in others and } \\
\text { thus, more susceptible to runoff. }\end{array}$ \\
\hline \multicolumn{2}{|l|}{ Trans port } \\
\hline Erosion & Total $\mathrm{P}$ loss is strongly related to erosion. \\
\hline Surface runoff & Water has to move off or through a soil for $\mathrm{P}$ to move. \\
\hline Subsurface flow & In sandy, organic, or P-saturated soils, $\mathrm{P}$ can be leached. \\
\hline Soil texture & Influences relative proportions of surface and subsurface flow. \\
\hline Connectivity to stream & The closer the field to the stream, the greater the chance of $\mathrm{P}$ reaching it. \\
\hline Channel effects & $\begin{array}{l}\text { Eroded material and associated P can be deposited or resuspended with a } \\
\text { change in stream flow. Dissolved P can be sorbed or desorbed by stream } \\
\text { channel sediments and bank material. }\end{array}$ \\
\hline Proximity of $\mathrm{P}$-sensitive water & $\begin{array}{l}\text { Some watersheds are closer to P-sensitive waters than others (i.e., point of } \\
\text { impact). }\end{array}$ \\
\hline Sensitivity P input & $\begin{array}{l}\text { Shallow lakes with large surface area tend to be more vulnerable to } \\
\text { eutrophication. }\end{array}$ \\
\hline
\end{tabular}


A. Input of $P$

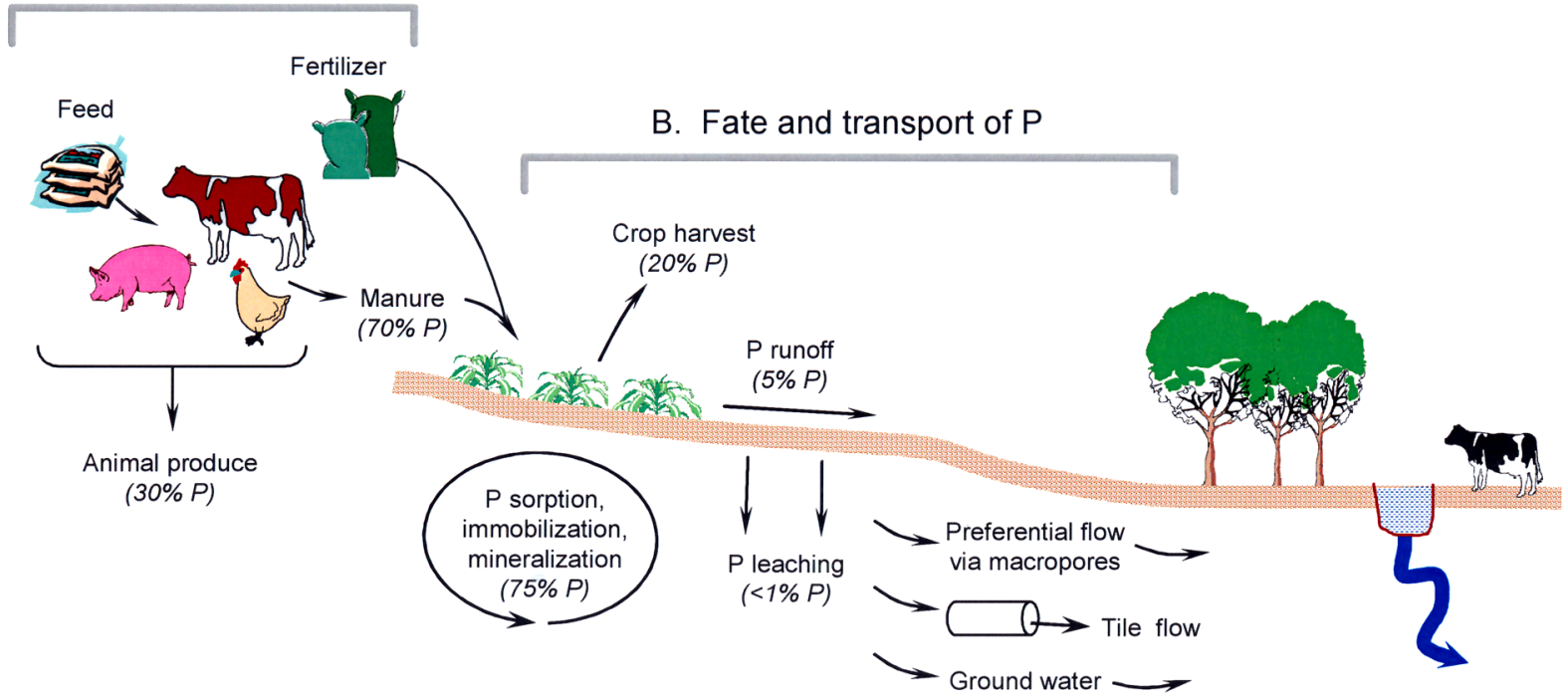

Figure 4 - Factors affecting the input, fate, and transport of $\mathrm{P}$ in agricultural systems. Numbers in parentheses are based on approximate farm inputs of $\mathrm{P}$ in animal feed and fertilizer and output in animal produce (A) and manure and fate in soils, crops, and transport in runoff (B). Adapted from Howarth et al. (2000) and Sims and Sharpley (2005).

noncultivated soils carries little sediment, and is, therefore, generally dominated by dissolved P (up to $80 \%$ of P) (Smith et al., 1991; Hart et al., 2004). Thus, erosion control is of prime importance in minimizing $\mathrm{P}$ loss from agricultural land. It may not, however, be sufficient in and of itself. Dissolved P originates from the release of $\mathrm{P}$ from soil, plants, and added fertilizer or manure (Figure 4). The release of $\mathrm{P}$ occurs when rainfall or irrigation water interacts with a thin layer of surface soil $(1$ to $5 \mathrm{~cm})$ and plant material before leaving the field as surface runoff (Sharpley, 1985). While dissolved $\mathrm{P}$ is immediately available for biological uptake, sediment $\mathrm{P}$ is not readily available but can be a long-term source of P for algae (Sharpley, 1993).

Generally, P loss in surface runoff is much greater than in subsurface flow and is dependent on the rate, time, and method of $\mathrm{P}$ application; form of fertilizer or manure applied; amount and time of rainfall after application; and land cover (Andraski et al., 2003; Sharpley \& Rekolainen, 1997). However, P loss by leaching can occur in sandy, organic, or peaty soils those with low $\mathrm{P}$ adsorption capacities; and in soils with substantial preferential flow pathways (Djodjic et al., 2004; Sims et al., 1998; Van Es et al., 2004) (Figure 4). Even so, P losses are often agronomically small (generally $<2 \mathrm{~kg} \mathrm{P} \mathrm{ha}{ }^{-1}$ ), representing a minor proportion of applied fertilizer or manure $\mathrm{P}$ (generally $<5 \%$; Figure 4). Phosphorus uptake and harvest removal by crops ranges from 10 to $30 \%$ of applied $\mathrm{P}$ (on average $20 \%$; Figure 4), due to the rapid and only slowing reversible sorption of $\mathrm{P}$ to $\mathrm{Al}, \mathrm{Fe}$, and $\mathrm{Ca}$ compounds in soil.
In Brazil, the predominance of Oxisols, rich in $\mathrm{Al}$ and $\mathrm{Fe}$ amorphous complexes tightly sorb large amounts of P (Fontes \& Weed, 1991; Novais \& Smyth, 1999). These soils occupy the major areas already developed for agricultural use, and are thus extremely important to crop and animal production and the overall economic viability of Brazilian agriculture (Fontes, 1996). This suggests that a major pathway for P loss from these Oxisols is going to be bound to sediment in surface runoff. This has important implications to the type of measures that would be needed to address P-related water quality problems. However, the amount of $\mathrm{P}$ loss necessary to cause water quality problems usually is very small compared to the amounts required by crops or contained in typical manure or fertilizer $\mathrm{P}$ applications. For example, lake water concentrations of $\mathrm{P}$ above $0.025 \mathrm{mg} \mathrm{L}^{-1}$ generally accelerate eutrophication (Table 3; Von Sperling, 1996). These values are an order of magnitude lower than $\mathrm{P}$ concentrations in soil solution critical for plant growth $(0.2$ to $0.3 \mathrm{mg}$ $\mathrm{L}^{-1}$ ), emphasizing the disparity between critical lake and soil $\mathrm{P}$ concentrations.

The loss of $\mathrm{P}$ in both surface and subsurface runoff has been shown to be related to the soil test $\mathrm{P}$ content of surface soils (McDowell \& Sharpley, 2001; Simard et al., 2000). Thus, conventional soil P tests have been used to estimate a soil's potential to enrich runoff with P (Andraski et al., 2003; Daverede et al., 2003; Pote et al., 1996; Tarkalson \& Mikkelsen, 2004a; Torbert et al., 2002). Although current soil test $P$ methods used in Brazil (resin and Mehlich-1) were developed to estimate 
plant availability of soil $\mathrm{P}$, it is likely that they can also be used as surrogates of $\mathrm{P}$ loss potential. For instance, several studies have shown runoff $\mathrm{P}$ concentration to be closely related to resin and Mehlich-1 extractable soil P (Beck et al., 2004; Nair et al., 2004; Sharpley, 1995).

Surface runoff generally occurs only from limited source areas within a watershed. These source areas vary rapidly in time, expanding and contracting quickly during a storm as a function of rainfall intensity and duration, antecedent moisture conditions, temperature, soils, topography, ground water, and moisture status over a watershed. Because surface runoff is the main mechanism by which $\mathrm{P}$ and sediment is exported from most watersheds, it is clear that $\mathrm{P}$ export by water will be negligible if surface runoff does not occur. Thus, consideration of how water moves and where surface runoff occurs is criti-

Table 3 - Approximate total P concentrations in fresh surface waters that define trophic status (Von Sperling, 1996).

\begin{tabular}{lc}
\hline Trophic status & Total P concentration in a watershed \\
\hline Ultraoligotrophic & $\mathrm{mg} \mathrm{L}^{-1}$ \\
Oligotrophic & $<0.005$ \\
Mesotrophic & $<0.010-0.020$ \\
Eutrophic & $0.010-0.050$ \\
Hypereutrophic & $0.025-0.100$ \\
\hline
\end{tabular}

cal to a more detailed understanding of $\mathrm{P}$ export from agricultural watersheds. Overall, critical areas of $\mathrm{P}$ loss occur where high sources of $\mathrm{P}$ (soil $\mathrm{P}$ and $\mathrm{P}$ added) coincide with areas of high transport potential. Research in the Northeast U.S. has shown these critical source areas represent $<20 \%$ of watershed area, but they can contribute with most $(>80 \%)$ of $\mathrm{P}$ exported from a watershed (Gburek \& Sharpley, 1998; Pionke et al., 2000). It is expected that in Brazil, a similarly small, but critical area of a watershed contributes most to the $\mathrm{P}$ exported.

\section{REMEDIAL MEASURES}

Remedial measures must begin with the longterm objective of increasing P use-efficiency, by attempting to balance $\mathrm{P}$ inputs within a watershed with $\mathrm{P}$ outputs, while simultaneously improving management of soil, manure, and mineral fertilizer P (Figure $5)$. There are several measures that can be used to reduce $P$ loss in agricultural runoff. These measures aim to control $\mathrm{P}$ loss by decreasing the sources of $\mathrm{P}$ that could be transported in runoff and the potential for transport (i.e., runoff and erosion) itself to occur (Table 4). As swine and poultry operations have led to a potential imbalance of $\mathrm{P}$ in the southern region of Brazil, the following discussion will focus on these types of animal operations.

Source Management - Source management attempts to minimize the buildup of $\mathrm{P}$ in the soil above levels sufficient for optimum crop growth, by

A. P source management

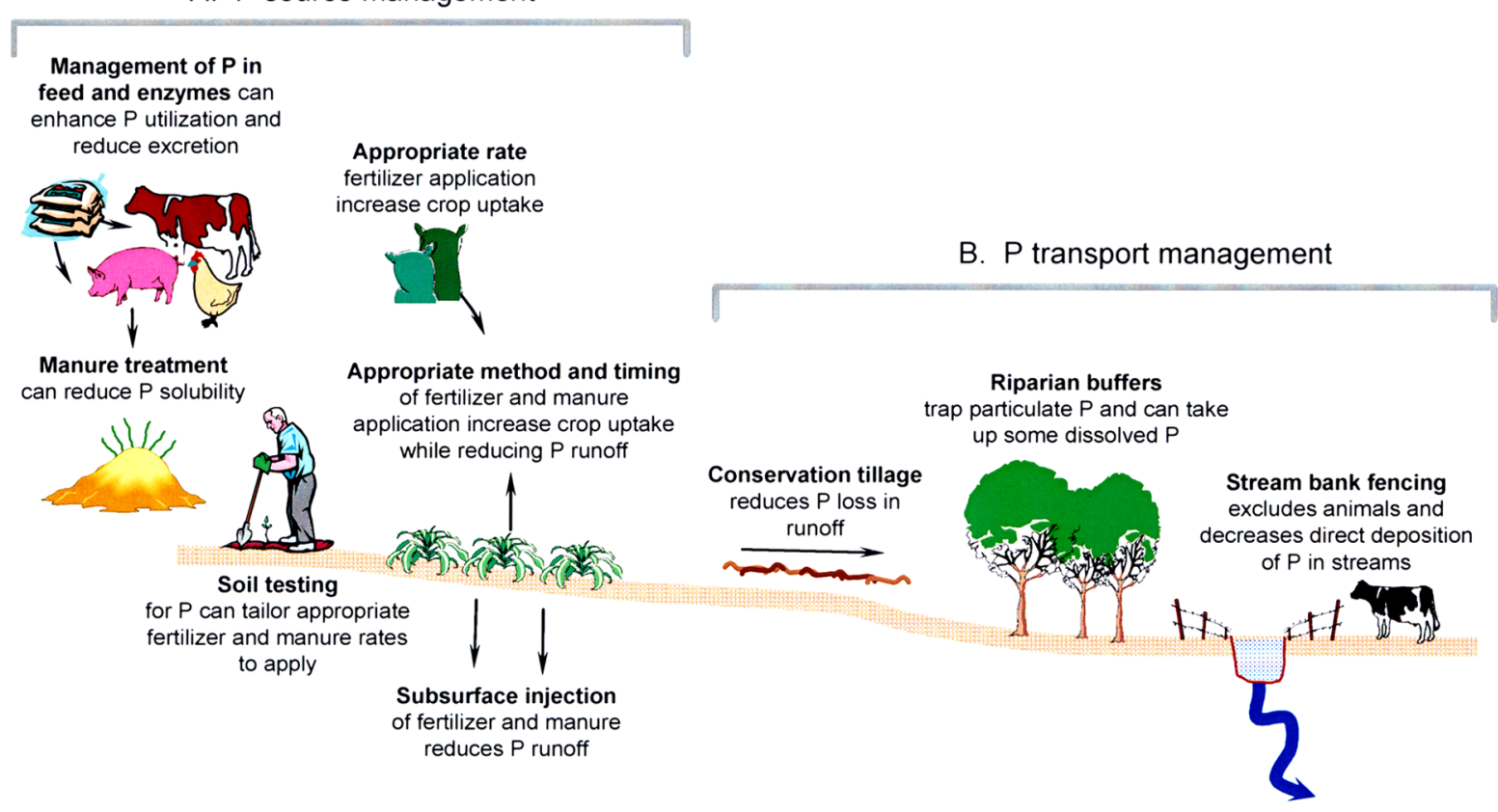

Figure 5 - The management of sources (A) and transport (B) of P on farms. 
Table 4 - Best Management Practices for the control of diffuse sources of agricultural P.

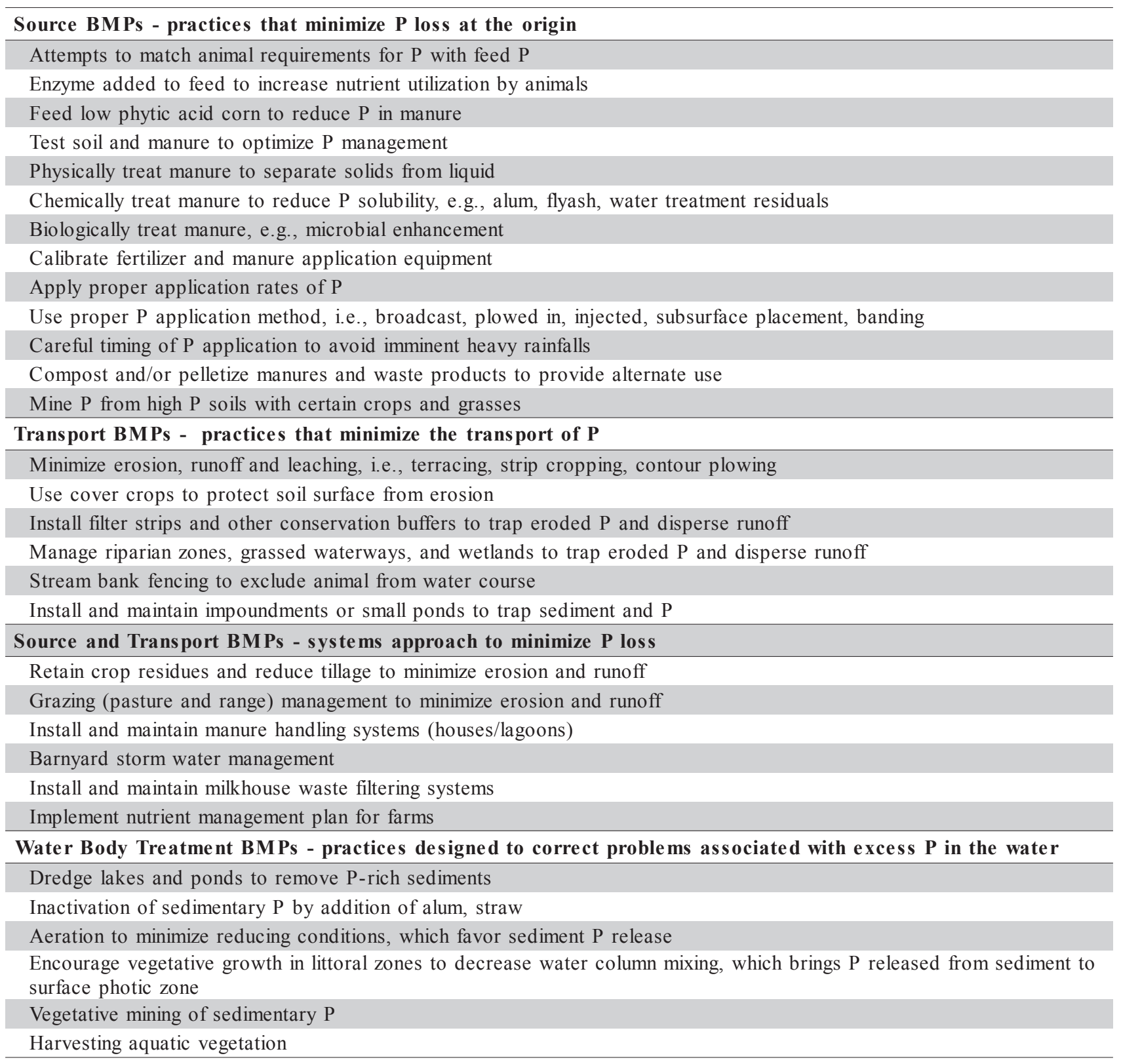

limiting the quantity of $\mathrm{P}$ in manure that must be applied to land, and controlling the amount of $\mathrm{P}$ that is applied in a localized area. Several techniques for doing so will be described next: (1) manipulating animal intake of dietary $P$, (2) managing inorganic and protein supplements that contain $\mathrm{P},(3)$ using enzyme additives for animal feed, (4) using corn hybrids with less phytate $\mathrm{P},(5)$ before the land application of manure, determining the $\mathrm{P}$ content of both manure and soil, (6) using commercially available manure amendments, (7) physical treatment of manure to separate solids from liquids, (8) facilitating the movement of manure from surplus to deficit areas, (9) using innovative methods to transport manure, (10) composting manure, (11) using some manures as "bioenergy" sources, and (12) carefully manage the timing and method of $\mathrm{P}$ applications.

Manipulation of dietary $\mathrm{P}$ intake by animals will help balance farm $\mathrm{P}$ inputs and outputs in animal operations, once feed inputs are often the major cause of $\mathrm{P}$ surplus. Feeding beef, poultry, and swine more $\mathrm{P}$ than minimum dietary requirements does not seem to confer any growth, reproduction, or health advantage and is in fact, excreted (Cromwell, 2005; National Research Council, 2001; Patterson et al., 2005). Thus, carefully matching dietary $\mathrm{P}$ inputs to animal requirements, which means having more than one feeding management group and $\mathrm{P}$ level across the life cycle of 
an animal can reduce the amount of $\mathrm{P}$ animals excrete (Cerosaletti et al., 2004). For example, Hostetter et al. (2000) stated that the introduction of ration P levels tailored to a life cycle of a sow has lowered on-farm P use by 43\% between 1981 and 1999. While this had no disadvantage to sow performance, profitability increased and the environment benefited from decreased excretion of $\mathrm{P}$ (Hostetter et al., 2000). This reduction will have an obvious impact on farm $P$ balance by reducing the potential on-farm accumulation of $\mathrm{P}$, and decreasing the land base needed for a balanced P-management plan. For example, a survey of dairy farms in Wisconsin by Powell et al. (2002) showed that on farms where manure $\mathrm{P}$ exceeds crop $\mathrm{P}$ requirements, reducing dietary $\mathrm{P}$ to the $\mathrm{NRC}$ recommendation would reduce the number of farms and acreage with excess $\mathrm{P}$ balance by approximately two-thirds.

In addition to inorganic $P$ supplementation of animal feed, some protein supplements can contribute substantial amounts of $\mathrm{P}$ to animal diets (National Research Council, 2001). Common protein supplements vary greatly in cost and $\mathrm{P}$ content $(0.3$ to $4.7 \% \mathrm{P})$, and producers often select protein sources based on economics, not $\mathrm{P}$ content. For operations where an excess $\mathrm{P}$ balance exists, protein supplements with lower $\mathrm{P}$ concentrations should be selected.

A significant amount of the $\mathrm{P}$ in grain is in phytate (phytic acid) an organic form of $\mathrm{P}$ that is digested in low proportions by monogastric animals such as swine and poultry. As a result, it is common to supplement feed with mineral forms of $\mathrm{P}$ that are readily digestible. This supplementation contributes to $\mathrm{P}$ enrichment of manures and litters. Enzymes such as phytase, which break down phytate into forms available to monogastric animals, can be added to feed to increase the efficiency of grain $\mathrm{P}$ absorption by swine and poultry (Federation of Animal Science Societies, 2001). Such enzymes reduce the need for P supplements in feed and potentially reduce the total $\mathrm{P}$ content of manure.

Another approach to better balance farm $\mathrm{P}$ inputs and outputs is to increase the quantity of $\mathrm{P}$ in corn that is available to swine and poultry (Cromwell, 2005; Patterson et al., 2005). Corn hybrids are available which contain low amounts of indigestible phytate P. Swine and poultry fed "low-phytic acid" corn grain excreted 10 to $40 \%$ less $\mathrm{P}$ in manure than those fed conventional corn varieties (Ertl et al., 1998). This study also showed that $\mathrm{P}$ availability to non-ruminants from low-phytate, high available phosphate (HAP) corn is about two to three times higher than from normal corn. Currently, the challenge to plant breeders is to incorporate the low-phytate trait into commercial corn hybrids with other agronomically desirable traits. Combining use of phytase feed amendments and low- phytate corn resulted in a $60 \%$ reduction in $\mathrm{P}$ excreted by swine (Baxter et al., 1998).

Farm advisors and resource planners should recommend that the $\mathrm{P}$ content of both soil and manure be determined by soil test laboratories before land application of manure. Without these determinations, farmers and their advisors tend to underestimate the fertilizer value of manure and may therefore over-apply them in regard to $P$.

Commercially available amendments, such as slaked lime or alum, which are applied to animal bedding material, can reduce ammonia $\left(\mathrm{NH}_{3}\right)$ volatilization, leading to improved animal health and weight gains; they can also reduce the solubility of $\mathrm{P}$ in poultry litter by several orders of magnitude; and decrease dissolved $\mathrm{P}$, metal, and hormone concentrations in surface runoff (Moore et al., 2000; Vadas et al., 2004). Perhaps the most important benefit of manure amendments for both air and water quality, would be an increase in the $\mathrm{N}: \mathrm{P}$ ratio of manure, via reduced $\mathrm{P}$ in the manure and $\mathrm{N}$ loss because of $\mathrm{NH}_{3}$ volatilization. An increased $\mathrm{N}: \mathrm{P}$ ratio of manure would more closely match crop $\mathrm{N}$ and $\mathrm{P}$ requirements.

Swine and dairy operations commonly rely on flush-water system for managing their manure. While such systems are very efficient, large volumes of slurry high in solids and soluble nutrients are produced. Because of the transportation cost involved with such volumes, the slurry is usually land applied in close proximity to the production houses, resulting in elevating the $\mathrm{P}$ content of the soil above that required by the crop. Separating the solids from the liquids during slurry storage produces a solid fraction that could be more easily transported than the bulkier slurry. Solid liquid separation also leaves large proportion of the available $\mathrm{N}$ in the liquid fraction and a larger proportion of the $\mathrm{P}$ will be in solid fraction. Coagulant and flocculent techniques commonly used by municipalities are being used to solve such problems (Timby et al., 2000). For example, use of a metal coagulant, such as aluminum in combination with commercial polymers (polyacrylamide), not only doubles the removal of solids but can dramatically reduce the soluble $\mathrm{P}$ in the effluent. It must be remembered, however, that manure treatment does not change the total amount of $\mathrm{P}$ that must be handled.

At the moment, manures are rarely transported more than $15 \mathrm{~km}$ from where they are produced. A program should be established to facilitate movement of manures from surplus to deficit areas. However, mandatory transport of manure from farms with surplus nutrients to neighboring farms where nutrients are needed faces several significant obstacles. First, it must be shown that manure-rich farms are unsuitable for 
manure application, based on soil properties, crop nutrient requirements, hydrology, actual $\mathrm{P}$ movement, and sensitive water-bodies. Conversely, it must be shown that the recipient farms are more suitable for manure application. The greatest success with re-distribution of manure nutrients is likely to occur when the general goals of nutrient management set by state governments are supported by consumers, local governments, the farm community, and the animal industry involved.

Composting, another potential tool, may also be considered as management tool to improve manure distribution. Because there is a wide range of composting methods, there is little consistency in the change of manure $\mathrm{P}$ form during composting, in terms of its availability or stability. However, as manure volume generally decreases during composting, $\mathrm{P}$ becomes more concentrated and transportation costs are reduced.

There is interest in using some manure as sources of "bioenergy." For example, dried poultry litter can be burned directly or converted by pyrolytic methods into oils suitable for use to generate electric power. Liquid manures can be digested anaerobically to produce methane, which can be used for heat and energy. As there is little change in the amount of total $\mathrm{P}$, an important part of any manure to energy approach must include a plan for utilizing the nutrient-rich residue.

Consideration of the rate, timing, and method of $\mathrm{P}$ applications can reduce the potential for $\mathrm{P}$ loss in runoff. As we have shown, $\mathrm{P}$ loss in runoff increases with greater rates and frequency of applied mineral fertilizer or manure (Edwards \& Daniel, 1993; Sharpley et al., 1998). Several studies have shown a decrease in $\mathrm{P}$ loss with an increase in the length of time between manure application and surface runoff (Djodjic et al., 2000; Sharpley, 1997; Westerman et al., 1983). This decrease can be attributed to the reaction of added $\mathrm{P}$ with soil and dilution of applied $\mathrm{P}$ by infiltrating water from rainfall that did not cause surface runoff. For instance, in fieldbased rainfall simulation studies, Sharpley et al. (2001) observed that the dissolved P concentration of surface runoff from the Berks silt loam (Typic Dystrochrept) decreased from 2.75 to $0.40 \mathrm{mg} \mathrm{L}^{-1}$ when rainfall occurred 35 days rather than two days after a surface broadcast application of $100 \mathrm{~kg} \mathrm{P} \mathrm{ha}^{-1}$ as poultry manure.

Incorporation of manure into the soil profile either by tillage or subsurface placement decreases the potential for $\mathrm{P}$ loss in runoff by lowering the concentration of $\mathrm{P}$ at the soil surface and a reducing runoff volume (Mueller et al., 1984; Pote et al., 1996;
Tarkalson \& Mikkelsen, 2004b). The relative solubility of fertilizer $\mathrm{P}$ can also influence the amount and form of P transported in runoff (Hart et al., 2004). For instance, Sharpley et al. (1978) observed a slightly greater dissolved $\mathrm{P}$ loss in runoff following the application of monocalcium $\mathrm{P}$ (MCP - the main component of superphosphate) to a permanent pasture in New Zealand $\left(2.80 \mathrm{~kg} \mathrm{ha}^{-1}\right)$, compared to that with dicalcium P (DCP) $\left(2.17 \mathrm{~kg} \mathrm{ha}^{-1}\right)$, a slow release fertilizer. The difference was attributed to more rapid dissolution of MCP than DCP at the soil surface. However, an appreciably greater loss of sediment-bound $\mathrm{P}$ with DCP $\left(4.92 \mathrm{~kg} \mathrm{ha}^{-1}\right)$ than MCP $\left(2.63 \mathrm{~kg} \mathrm{ha}^{-1}\right)$, resulted from an increased loss of $\mathrm{P}$ by transport of the less soluble DCP particles in runoff.

Transport Management - Transport management refers to efforts to control the movement of $\mathrm{P}$ from soils to sensitive locations such as bodies of fresh water (Figure 5). Phosphorus loss via surface runoff and erosion may be reduced by conservation tillage and crop residue management, buffer strips, riparian zones, terracing, contour tillage, cover crops and impoundments (e.g., settling basins) (Table 4). These practices tend to reduce rainfall impact on the soil surface, reduce runoff volume and velocity, and increase soil resistance to erosion. Techniques for reducing the potential for transport to occur include: (1) conservation tillage, (2) cover crops, (3) grassed waterways, (4) conservation buffers, (4) barnyard runoff management, (5) stream-bank protection, and (6) constructed wetlands and sediment basins.

Conservation tillage practices are designed to reduce runoff and erosion and associated $\mathrm{P}$ losses. However, if manures are surface applied to maintain no-till residue compliances, the potential for $\mathrm{P}$ loss, particularly in the dissolved form, can be greater than for conventional tillage (Gaynor \& Findlay, 1995; Sharpley \& Smith, 1994). Thus, the subsurface application of manures by injection, for example, should be considered as part of conservation tillage, particularly no-till, in order to minimize runoff $P$ losses. Injection techniques that minimize surface disturbance are important so that erosion is not increased.

Cover crops serve to protect the soil surface from raindrop impact, improve infiltration relative to bare soil and trap eroded particles (Sharpley \& Smith, 1991). In areas where dissolved $P$ transport is the primary concern, cover crops may reduce runoff, and, consequently, runoff $\mathrm{P}$ load (mass), but are unlikely to impact dissolved $\mathrm{P}$ in runoff.

Grassed waterways are designed to reduce runoff velocity and reduce channel erosion. In some cases, 
grass diversions may be installed across a slope to intercept runoff and break up effective slope length (Chow et al., 1999). Riparian areas or in-field buffers can reduce erosion and P losses, as well as increase wildlife diversity and numbers and aquatic habitat (Lowrance et al., 1985; Peterjohn \& Correll, 1984; Uusi-Kämppä et al., 2000). In addition to acting as physical buffers to sediment-bound nutrients, plant uptake captures $\mathrm{P}$, resulting in a short-term and long-term accumulation of nutrients in biomass (Clausen et al., 2000; Jokela et al., 2004). However, the effectiveness of conservation buffer areas as nutrient buffers can vary significantly. For instance, the route and depth of subsurface water flow paths through riparian areas can influence nutrient retention. Conservation buffers are most efficient when sheet flow occurs, rather than channelized flow, which often bypass some of the retention mechanisms. Thus these areas must be carefully managed to realize their full retention and filtration capabilities.

Two fairly inexpensive transport BMPs associated with feedlots or animal loafing areas, are the installation of gutter and downspouts on barns and sheds. This is a simple way to divert clean rainfall water away from these areas and also reduce runoff volumes from the area. Similarly, a berm, constructed around the upslope side of the feedlots or loafing areas, can divert clean water and minimize the potential for runoff of $\mathrm{P}$ and erosion.

Stream-bank protection and fencing (for animal exclusion) can reduce erosional inputs of $\mathrm{P}$ and direct deposition of manure in streams, respectively. However, stream-bank protection and fencing have not been a popular practice with many farmers and thus, not widely implemented, due to high costs, maintenance needs, and removal of a cheap and readily available drinking water source for animal.

Constructed wetlands and sediment basins both serve to reduce particulate $\mathrm{P}$ by intercepting sedimentladen flow. Certain wetland plant species (e.g. Phragmites spp.) can substantially improve $\mathrm{P}$ removal efficiency from surface flow.

Despite these advantages, any one of these measures should not be relied upon as the sole or primary means of reducing $\mathrm{P}$ losses in agricultural runoff. These practices are generally more efficient at reducing sediment $\mathrm{P}$ than dissolved P. Also, P stored in stream and lake sediments can provide a long-term source of $\mathrm{P}$ in waters even after inputs from agriculture have been reduced. Thus, the effect of remedial measures in the contributing watershed will be slow for many cases of poor water quality. Therefore, immediate action may be needed to reduce future problems.

\section{CONCLUDING REMARKS}

Major changes in crop and animal production systems have taken place over the last 10 to 20 years on a global scale. Both crop and animal production became more intensive and specialized to meet population demands for low-cost yet high quality grain and protein sources. These systems now exist in spatiallyseparated areas because of cheap and effective transport networks that operate across regions and even countries. This has led to the one-way transfer of $\mathrm{P}$ from areas where rock $\mathrm{P}$ deposits are mined to areas of grain production to animal rearing facilities, where there is a consequent accumulation of $\mathrm{P}$ in manures. As this manure is land applied, soil $\mathrm{P}$ builds to levels that exceed crop needs and increases the potential for $\mathrm{P}$ in runoff. The potential for $\mathrm{P}$ loss and associated water quality impairment is exacerbated by the growth of animal operation in areas with inherently low soil productivity, where farmers have turned from growing crops to rearing animals to be economically viable (i.e., to continue being able to make a living from farming).

Brazil is no exception, with the major proportion of the country's swine and poultry production now occurring in the South and Southeast regions $(75 \%)$. We estimate that these animals produce 2.5 million tones of $\mathrm{P}$ in manure each year, nationally. Although there have been many studies on the effects of land applying manure and $\mathrm{P}$ on soil fertility and crop production, some of which we have presented, little information exists on resulting water quality impacts. We have demonstrated that this information is clearly needed to develop conservation practices that will minimize the potential for $\mathrm{P}$ runoff under Brazilian farming conditions. Although lessons can be learnt from other regions of the world, conservation practices must be tailored to local land and economic constraints.

There are several measures available to minimize the potential for $\mathrm{P}$ loss in agricultural runoff, which address sources and transport of $\mathrm{P}$. The main measures that should be considered are those that attempt to decrease the surplus of $\mathrm{P}$ in localized areas through dietary $\mathrm{P}$ reduction, feed additives that enhance $\mathrm{P}$ utilization by animals, alternative uses for manure other than land application, and transporting manure to P-deficient areas. Other measures, which attempt to reduce the loss in runoff, will only provide short-term benefits unless P surpluses are diminished. These measures include the use of soil $\mathrm{P}$ tests that estimate environmental rather than agronomic thresholds, manure application rates based on soil $\mathrm{P}$ and crop needs, as well as adopting conservation tillage and buffer zones that limit soil and associated $\mathrm{P}$ entering 
streams. Even so, these measures should be targeted to critical source areas where most of the runoff originates. Finally, a financial infrastructure needs to be established that will support implementation of the above remedial measures, as well as the dissemination of technically sound advice to all farmers, policy makers, and affected public. Water quality impairment is extremely difficult to reverse and the longer we wait to address the sources of $\mathrm{P}$ (e.g., agriculture, municipal, urban), the more expensive remedial measures will become.

Research to address agricultural P-related should fall into four general areas: (1) assess the extent of $\mathrm{P}$ related water quality problems - is this a widespread or localized problem?; (2) evaluate farm P budgets (how much $\mathrm{P}$ input in feed and fertilizer minus output in produce) to determine the extent to which $\mathrm{P}$ surpluses occur - is this a small or large farm problem?; (3) determine the level of $\mathrm{P}$ in soils of impaired areas and how easily this is released to runoff water is this a land use problem?; and (4) evaluate conservation or BMP measures on $\mathrm{P}$ loss (e.g., conservation tillage, buffers, and manure management) - what can be done?

\section{ACKNOWLEDGEMENT}

Funding for Francirose Shigaki to complete this research was provided by CAPES, Brazil. Luís Ignácio Prochnow expresses his gratitude to $\mathrm{CNPq}$ for the scholarship in research.

\section{REFERENCES}

ANDRASKI, T.W.; BUNDY, L.G. Relationship between phosphorus levels in soil and in runoff from corn production systems. Journal of Environmental Quality, v.32, p.310-316, 2003.

ANDRASKI, T.W.; BUNDY, L.G.; KILIAN, K.C. Manure history and long-term tillage effects on soil properties and phosphorus losses in runoff. Journal of Environmental Quality, v.32, p.1782-1789, 2003.

BARNABE, M.C. Produção e composição bromatológica de Brachiaria Brizantha cv. Marandu adubada com dejetos de suinos. Goiânia: UFG/ EV, 2001. 60p. (Dissertacao - Mestrado).

BAXTER, C.A.; JOERN; B.C.; ADEOLA, L.; BROKISH, J.E. Dietary $P$ management to reduce soil $P$ loading from pig manure. Johnston: Pioneer Hybrid International Inc., 1998. p.1-6. (Annual Progress Report).

BECK, M.A.; ZELAZNY L.W.; DANIELS, W.L.; MULLINS, G.L. Using Mehlich-1 extract to estimate soil phosphorus saturation for environmental risk assessment. Soil Science Society of America Journal, v.68, p.1762-1771, 2004.

BEEGLE, D.B. Soil fertility management. In: MARTZ E. (Ed.). Agronomy guide 2002. University Park: College of Agricultural Sciences, The Pennsylvania State University, 2002. p.18-42.

BRASIL. Ministerio da Agricultura, Pecuaria e Abastecimento. Agronegocio brasileiro: Uma oportunidade de investimentos. Brasilia, 2004. (MAPA Estatísticas). Available in: <http:// www.agricultura.gov.br/portal/page?_pageid= $33,968707 \& \_$dad $=$portal\&_schema=PORTAL $>$. Accessed at: August 9, 2005.
BURKHOLDER, J.A.; GLASGOW JR., H.B. Pfiesteria piscicidia and other Pfiesteria-dinoflagellates behaviors, impacts, and environmental controls. Limnology and Oceanography, v.42, p. 1052-1075, 1997.

CARPENTER, S.R.; CARACO, N.F.; CORRELL, D.L.; HOWARTH, R.W.; SHARPLEY, A.N.; SMITH, V.H. Nonpoint pollution of surface waters with phosphorus and nitrogen. Ecological Applications, v.8, p.559-568, 1998.

CEROSALETTI, P.E.; FOX, D.G.; CHASE, L.E. Phosphorus reduction through precision feeding of dairy cattle. Journal of Dairy Science, v.87, p.2314-2323, 2004.

CHOW, T.L.; REES, H.W.; DAIGLE, J.L. Effectiveness of terraces/ grassed waterway systems for soil and water conservation: a field evaluation. Journal of Soil and Water Conservation, v.54, p.577$583,1999$.

CLAUSEN, J.C.; GUILLARD, K.; SIGMUND, C.M.; DORS, K. MARTIN. Water quality changes from riparian buffer restoration in Connecticut. Journal of Environmental Quality, v.29, p.1751-1761, 2000.

CROMWELL, G.L. Phosphorus and swine nutrition. In: SIMS, J.T.; SHARPLEY, A.N. (Ed.). Phosphorus; Agriculture and the environment. Madison: ASA, 2005. chap.4, p.607-634.

DANIEL, T.C.; SHARPLEY, A.N.; LEMUNYON, JL. Agricultural phosphorus and eutrophication. Journal of Environmental Quality, v.27, p.251-257, 1998.

DAVEREDE, I.C.; KRAVCHENKO, A.N.; HOEFT, R.G.; NAFZIGER, E.D.; BULLOCK, D.G.; WARREN, J.J.; GONZINI, L.C. Phosphorus runoff: Effect of tillage and soil phosphorus levels. Journal of Environmental Quality, v.32, p.1436-1444, 2003.

DIESEL, R.; MIRANDA, C.R.; PERDOMO, C.C. Coletania de tecnologias sobre dejetos suinos. Concordia: Embrapa Suinos e Aves; Emater/RG, 2002.31p.

DJODJIC, F.; ULEN, B.; BERGSTROM, L. Temporal and spatial variations of phosphorus losses and drainage in a structured clay soil. Water Research, v.34, p.1687-1695, 2000.

DJODJIC, F.; BORLING, K.; BERGSTROM, L. Phosphorus leaching in relation to soil type and soil phosphorus content. Journal of Environmental Quality, v.33, p.678-684, 2004.

EDWARDS, D.R.; DANIEL, T.C. Runoff quality impacts of swine manure applied to fescue plots. Transaction of the ASAE, v.3, p.81-80, 1993.

ERTL, D.S.; YOUNG, K.A.; RABOY, V. Plant genetic approaches to phosphorus management in agricultural production. Journal of Environmental Quality, v.27, p.299-304, 1998.

EVANS, R.; CUFFMAN-NEFF, L.C.; NEHRING, R. Increases in agricultural productivity, 1948-1993. Washington: USDA Economic Research Service, 1996. 85p. (Updates on Agricultural Resources and Environmental Indicators, 6).

FAO. Country profiles, maps. Rome. Available on: http://www.fao.org/ countryprofiles/Maps/BRA/06/pp/index.html. Acessed at: August 9, 2005.

FEDERATION OF ANIMAL SCIENCE SOCIETIES. Effects of diet and feeding management on nutrient contents of manure. Washington, DC., 2001. 4p.

FONTES, M.P.F. Phosphate adsorption by clays from Brazilian Oxisols: relationship with specific area and mineralogy. Geoderma, v.72, p.31-51, 1996.

FONTES, M.P.F.; WEED, S.B. Iron oxides in selected Brazilian Oxisols: I. Mineralogy. Soil Science Society of American Journal, v.55, p.1150-1155, 1991.

GARDNER, G. Recycling organic wastes. In: BROWN, L.; FLAVIN, C.; FRENCH, H. (Ed.). State of the world. New York: W.W. Norton, 1998. p.96-112.

GAYNOR, J.D.; FINDLAY, W.I. Soil and phosphorus loss from conservation and conventional tillage in corn production. Journal of Environmental Quality, v.24, p.734-741, 1995.

GBUREK, W.J.; SHARPLEY, A.N. Hydrologic controls on phosphorus loss from upland agricultural watersheds. Journal of Environmental Quality, v.27, p.267-277, 1998.

HART, M.R.; QUIN, B.F.; NGUYEN, M.L. Phosphorus runoff form agricultural land and direct fertilizer effects: A review. Journal of Environmental Quality, v.33, p.1954-1972, 2004. 
HAYGARTH, P.M.; CHAPMAN, P.J.; JARVIS, S.C.; SMITH, R.V. Phosphorus budgets for two contrasting grassland farming systems in the UK. Soil Use and Management, v.14, p.160-167, 1998.

HEANEY, S.I.; FOY, R.H.; KENNEDY, G.J.A.; CROZIER, W.W.; O'CONNOR, W.C.K. Impacts of agriculture on aquatic systems: lessons learnt and new unknowns in Northern Ireland. Journal of Marine and Freshwater Research, v.52, p.151-163, 2001.

HOFFMAMM, I.; GERLING, D.; KYIOGWOM, U.B.; MANEBIELFELDT, A. Farmers management strategies to maintain soil fertility in a remote area in northwest Nigeria. Agriculture Ecosystems and the Environment, v.86, p.263-275, 2001.

HOGBERG, M.G.; FALS, S.L.; KIRSCHENMANN, F.L.; HONEYMAN, M.S.; MIRANOWSKI, J.A.; LASLEY, P. Interrelantiononship of animal agriculture, the environment, and rural communities. Journal of Animal Science, v.81, p.E13-E17, 2005.

HOSTETTER, J.; BRUBAKER, D.; CARMEAN, W.; GARRETT, T. Perspectives of Bay users. In: SHARPLEY, A.N. (Ed.). Agriculture and phosphorus management: The Chesapeake Bay. Boca Raton: CRC Press, 2000. p.181-186.

HOWARTH, R.W.; ANDERSON, D.A.; CHURCH, T.M., GREENING, H.; HOPKINSON, C.S.; HUBER, W.; MARCUS, N.; NAIMAN, R.J.; SEGERSON, K.; SHARPLEY, A.N.; WISEMAN, JR., W.J. Clean coastal waters: Understanding and reducing the effects of nutrient pollution. Washington: National Research Council, 2000. 405p.

INSTITUTO BRASILEIRO DE GEOGRAFIA E ESTATISTICA IBGE. Pesquisa municipal de producao animal. Brasília, 2003. Available on: http://www.sidra.ibge.gov.br/bda/tabela/ listabl.asp? $\mathrm{z}=\mathrm{t} \& \mathrm{c}=73$. Accessed at: August 9, 2005.

JOKELA, W.E.; CLAUSEN, J.C.; MEALS, D.W.; SHARPLEY, A.N Effectiveness of agricultural best management practices in reducing phosphorous loading to Lake Champlain. In: MANLEY, T.O.; MANLEY, P.L.; MIHUC, T.B. (Ed.). Lake Champlain: Partnerships and Research in the New Millennium. Dordrecht: Kluwer Academic Publishers, 2004. p.39-53.

KELLOGG, R.L.; LANDER, C.H.; MOFFITT, D.C.; GOLLEHON, N. Manure nutrients relative to the capacity of cropland and pastureland to assimilate nutrients: Spatial and temporal trends for the United States. Fort Worth, TX: USDA, Natural Resources Conservation Service and Economic Research Service, 2000. 140p. (Resource Assessment and Strategic Planning Working Paper, 981). Available in: http://www.nrcs.usda.gov/technical/land/pubs/ manntr.pdf. Accessed at: August 9, 2005.

KLEINMAN, P.J.A.; WOLF, A.M.; SHARPLEY, A.N.; BEEGLE, D.B.; SAPORITO, L.S. Survey of water extractable phosphorus in livestock manures. Soil Science Society of America Journal, v.69, p.701$708,2005$.

KONZEN, E.A. Aproveitamento de dejetos liquidos de suinos para fertirrigacao e fertilizacao em grandes culturas. Sete Lagoas: Embrapa Milho e Sorgo, 2003a. 11p. (Circular Tecnica, 32).

KONZEN, E.A. Fertilizacao de lavoura e pastagem com dejetos suinos e cama de aves. Sete Lagoas: Embrapa Milho e Sorgo, $2003 \mathrm{~b}$. 10p. (Circular Tecnica, 31).

LANDER, C.H.; MOFFITT, D.; ALT, K. Nutrients available from livestock manure relative to crop growth requirements. Washington: USDA, Natural Resources Conservation Service, 1998. (Resource Assessment and Strategic Planning Working Paper, 981). Available in: <http://www.nrcs.usda.gov/technical/land/pubs/ nlweb.html>. Accessed at: August 9, 2005.

LANYON, L.E. Nutrient management: Regional issues affecting the Chesapeake Bay. In: SHARPLEY, A.N. (Ed.). Agriculture and phosphorus management: The Chesapeake Bay. Boca Raton: CRC Press, 2000. p.145-158.

LOWRANCE, R.R.; LEONARD, R.A.; SHERIDAN, J.M. Managing riparian ecosystems to control non-point pollution. Journal of Soil and Water Conservation, v.40, p.87-91, 1985.

McDOWELL, L.L.; McGREGOR, K.C. Plant nutrient losses in runoff from conservation tillage corn. Soil and Tillage Research, v.4, p.7991, 1984.
McDOWELL, R.W.; SHARPLEY, A.N. Approximating phosphorus release from soils to surface runoff and subsurface drainage. Journal of Environmental Quality, v.30, p.508-520, 2001.

McDOWELL, R.W.; SHARPLEY, A.N. The effects of soil carbon on phosphorus and sediment loss from soil trays by overland flow. Journal of Environmental Quality, v.32, p.207-214, 2003.

MIRANDA, C.R. DE.; ZARDO, A.O.; GOSMANN, H. A. Uso de dejetos de suinos na agricultura. Instrucoes Tecnicas para o Suinocultor. Concordia: Embrapa Suinos e Aves, 1999. 2p.

MOORE JR., P.A.; DANIEL, T.C.; EDWARDS, D.R. Reducing phosphorus runoff and inhibiting ammonia loss from poultry manure with aluminum sulfate. Journal of Environmental Quality, v.29, p.37-49, 2000.

MUELLER, D.H.; WENDT, R.C.; DANIEL, T.C. Phosphorus losses as affected by tillage and manure application. Soil Science Society of America Journal, v.48, p.901-905, 1984.

MULLINS, G.L.; JOERN, B.C.; MOORE, JR. P.A. By-product phosphorus: Sources, characteristics, and management. In: SIMS, J.T.; SHARPLEY, A.N. (Ed.). Phosphorus; Agriculture and the environment. Madison: ASA, 2005. p.829-880.

NAIR, V.D.; PORTIER, K.M.; GRAETZ, D.A.; WALKER, M.L. An environmental threshold for degree of phosphorus saturation in sandy soils. Journal of Environmental Quality, v.33, p.107-113, 2004.

NATIONAL RESEARCH COUNCIL. Nutrient requirements of dairy cattle. 7.ed. Washington, DC: National Academic Sciences, 2001.

NEW ZEALAND. Ministry for the Environment. The state of New Zealand's environment 1997. Wellington: GP Publications, 1997. chap.7, p.1-100: The state of our waters.

NONES, L.K.; LIMA, G.J.M.M. DE.; BELLAVER, C.; RUTZ, F. Formulação das dietas, desempenho e qualidade da carcaça, produção e composição de dejetos de suínos. Scientia Agricola, v.59, p.635644, 2002

NOVAIS, R.F.; SMYTH, T.J. Fósforo em solo e planta em condições tropicais. Viçosa: UFV, 1999. 399p.

OLIVEIRA, P.A.V. de. Tecnologia para o manejo de residuos na producao de suinos: Manual de boas praticas. Concordia: Emprapa Suínos e Aves, 2004. 109p.

PATTERSON, P.; MOORE JR., P.A.; ANGEL; R. Phosphorus and poultry nutrition. In: SIMS, J.T.; SHARPLEY, A.N. (Ed.). Phosphorus; Agriculture and the environment. Madison: ASA, 2005. chap. 4, p.635-682.

PETERJOHN, W.T.; CORRELL, D.L. Nutrient dynamics in an agricultural watershed: Observations on the role of a riparian forest. Ecology, v.65, p.1466-1475, 1984.

PIONKE, H.B.; GBUREK, W.J.; SHARPLEY, A.N. Critical source area controls on water quality in an agricultural watershed located in the Chesapeake Basin. Ecological Engineering, v. 14, p.325-335, 2000.

POTE, D.H.; DANIEL, T.C.; SHARPLEY, A.N.; MOORE JR., P.A.; EDWARDS, D.R.; NICHOLS, D.J. Relating extractable soil phosphorus to phosphorus losses in runoff. Soil Science Society of America Journal, v.60, p.855-859 1996.

POTAFOS. Potash and Phosphate Institute. Consumption of fertilizers per region. Piracicaba, 2006. Available on: http://www.potafos.org/ ppiweb/brazil.nsf/\$webindex/7A41892BCC7634FB 83 256B1200656701?opendocument\&navigator $=$ profile. Accessed at: August 9, 2005.

POWELL, J.M.; JACKSON-SMITH, D.B.; SATTER, L.D. Phosphorus feeding and manure nutrient recycling on Wisconsin dairy farms. Nutrient Cycling in Agroecosystems, v.62, p.277-286, 2002.

SEGANFREDO, M.A. Analise dos risco de poluição do ambiente, quando se usa dejetos de suinos como adubo do solo. Concórdia: Embrapa Suínos e Aves, 2000. p.1-3. (Comunicado Técnico, 268).

SEGANFREDO, M.A. Os dejetos de animais podem causar poluição também nos solos de baixa fertilidade e nos solos profundos, como aqueles da região dos cerrados. Concórdia: Embrapa Suínos e Aves, 2001a. 4p. (Comunicado Técnico, 292).

SEGANFREDO, M.A. A aplicação do principio do balanço de nutrientes no planejamento do uso de dejetos de animais para adubação orgânica. Concórdia: Embrapa Suínos e Aves, 2001b. 6p. (Comunicado Técnico). 
SCHINDLER, D.W. Evolution of phosphorus limitation in lakes. Science, v.195, p.260-262, 1977.

SHARPLEY, A.N. Depth of surface soil-runoff interaction as affected by rainfall, soil slope, and management. Soil Science Society of America Journal, v.49, p.1010-1015, 1985.

SHARPLEY, A.N. Assessing phosphorus bioavailability in agricultural soils and runoff. Fertilizer Research, v.36, p.259-272, 1993.

SHARPLEY, A.N. Dependence of runoff phosphorus on extractable soil phosphorus. Journal of Environmental Quality, v.24, p.920-926, 1995.

SHARPLEY, A.N. Rainfall frequency and nitrogen and phosphorus in runoff from soil amended with poultry litter. Journal of Environmental Quality, v.26, 1127-1132, 1997.

SHARPLEY, A.N. (Ed.). Agriculture and phosphorus management: The Chesapeake Bay. Boca Raton: CRC Press, 2000. 229p.

SHARPLEY, A.N.; SMITH, S.J. Effect of cover crops on surface water quality. In: HARGROVE, W. L. (Ed.). Cover crops for clean water. Ankeny: Soil and Water Conservation Society, 1991. p.41-50.

SHARPLEY, A.N.; SMITH; S.J. Wheat tillage and water quality in the Southern Plains. Soil and Tillage Research, v.30, p.33-38, 1994.

SHARPLEY, A.N.; REKOLAINEN, S. Phosphorus in agriculture and its environmental implications. In: TUNNEY, H.; CARTON, O.T.; BROOKES, P.C.; JOHNSTON, A.E. (Ed.). Phosphorus loss from soil to water. Arlington: $\mathrm{CAB}$ International, 1997. p.1-54.

SHARPLEY, A.N.; MOYER, B. Forms of phosphorus in manures and composts and their dissolution during rainfall. Journal of Environmental Quality, v.29, p.1462-1469, 2000.

SHARPLEY, A.N.; TUNNEY, H. Phosphorus research strategies to meet agricultural and environmental challenges of the 21 st century. Journal of Environmental Quality, v.29, p.176-181, 2000.

SHARPLEY, A.N.; SYERS, J.K.; GREGG, P.E.H. Transport of phosphorus from superphosphate and dicalcium phosphate in surface runoff from pasture. New Zealand Journal of Science, v.21, p.307310, 1978

SHARPLEY, A.N.; MEISINGER, J.J.; BREEUWSMA, A.; SIMS, J.T.; DANIEL, T.C.; SCHEPERS, J.S. Impacts of animal manure management on ground and surface water quality. In: HATFIELD, J.L.; STEWART, B.A. (Ed.). Animal waste utilization: Effective use of manure as a soil resource. Boca Raton: Ann Arbor Press, 1998. p.173-242.

SHARPLEY, A.N.; MCDOWELL, R.W.; KLEINMAN, P.J.A. Phosphorus loss from land and water: Integrating agricultural and environmental management. Plant and Soil, v.237, p.287-307, 2001.

SIMARD, R.R.; BEAUCHEMIN, S.; HAYGARTH, P.M. Potential for preferential pathways of phosphorus transport. Journal of Environmental Quality, v.29, p.97-105, 2000.

SIMS, J.T.; KLEINMAN, P.J.A. Managing agricultural phosphorus for environmental protection. In: SIMS, J.T.; SHARPLEY, A.N. (Ed.). Phosphorus; Agriculture and the environment. Madison: ASA, 2005. p.1021-1068.

SIMS, J.T.; JOERN, B.C.; SIMARD, R.R. Phosphorus losses in agricultural drainage: Historical perspective and current research. Journal of Environmental Quality, v.27, p.277-293, 1998.

SMITH, S.J.; SHARPLEY, A.N.; NANEY, J.W.; BERG, W.A.; JONES, O.R. Water quality impacts associated with wheat culture in the Southern Plains. Journal of Environmental Quality, v.20, p.244249, 1991.

TARKALSON, D.D.; MIKKELSEN, R.L. Runoff phosphorus losses as related to soil test phosphorus and degree of phosphorus saturation on Piedmont soils under conventional and no-tillage. Communications in Soil Science and Plant Analysis, v.35, p.29873007, 2004a.

TARKALSON, D.D.; MIKKELSEN, R.L. Runoff phosphorus losses as related to phosphorus source, application method, and application rate on a Piedmont soil. Journal of Environmental Quality, v.33, p.1424-1430, 2004b.
TIMBY, G.G.; DANIEL, T.C.; MOORE JR., P.A. Solids and phosphorus removal from flushed dairy manure using organic polymers and aluminum chloride. Agronomy Abstracts, p.309, 2000.

TORBERT, H.A.; DANIEL, T.C.; LEMUNYON, J.L.; JONES, R.M. Relationship of soil test phosphorus and sampling depth to runoff phosphorus in calcareous and noncalcareous soils. Journal of Environmental Quality, v.31, p.1380-1387, 2002.

U.S. DEPARTMENT OF AGRICULTURE. U.S. ENVIRONMENTAL PROTECTION AGENCY. Unified national strategy for animal feeding operations. Washington, DC: U.S. Government Printing Office, 1999. Available in: http://cfpub.epa.gov/npdes/afo/ ustrategy.cfm?program_id=7. Accessed at: August 9, 2005.

U.S. ENVIRONMENTAL PROTECTION AGENCY. The Total Maximum Daily Load (TMDL) program. Washington, DC: U.S. EPA, 2000. (EPA 841-F-00-009). Available in: http://www.epa.gov/ owow/tmdl/overviewfs.html. Accessed at: August 9, 2005.

U.S. ENVIRONMENTAL PROTECTION AGENCY. Managing manure nutrients at concentrated animal feeding operations. Washington, DC: U.S. Environmental Protection Agency, 2004. (EPA-821-B-04-006). Available on: http://www.epa.gov/guide/cafo/ Accessed at: August 9, 2005.

U.S. GEOLOGICAL SURVEY. The quality of our nation's waters: Nutrients and pesticides. Denver: USGS Information Services, 1999. 82p. (Circular, 1225). Available in: http://www.usgs.gov. Accessed at: August 9, 2005.

UUSI-KÄMPPÄ, J.; BRASKERUD, B.; JANSSON, H.; SYVERSON, $\mathrm{N}$.; UUSITALO, R. Buffer zones and constructed wetlands as filters for agricultural phosphorus. Journal of Environmental Quality, v.29, p.151-158, 2000.

VADAS, P.A.; MEISINGER, J.J.; SIKORA, L.J.; MCMURTRY, J.P.; SEFTON, A.E. Effect of poultry diet on phosphorus in runoff from soils amended with poultry manure and compost. Journal of Environmental Quality, v.33, p.1845-1854, 2004.

VAN ES, H.M.; SCHINDELBECK, R.R.; JOKELA, W.E. Effect of manure application timing, crop, and soil type on phosphorus leaching. Journal of Environmental Quality, v.33, p.1070-1080, 2004.

VIEIRA, F.C.B.; CERETTA, C.A.; BASSO, C.J.; DURIGON, R.; POLLETO, N. Aplicação de esterco líquido de suínos e características químicas de um solo sob pastagem natural. In: FERTBIO - 2000. Santa Maria, 2000. Santa Maria: SBCS; SBM, 2000. 1 CD-Rom.

VIEIRA, F.C.B.; HERBES, M.G.; CERETTA, C.A.; BASSO, C.J. Uso de esterco líquido de suíno na agricultura e evolução de $\mathrm{CO}_{2}$. In: FERTBIO - 2002. Rio de Janeiro, 2002. Agricultura: bases ecologicas para o desenvolvimento sustentado. Rio de Janeiro: SBCS; SBM; UFRJ, 2002. 1 CD-Rom.2002. CD-Rom.

VON SPERLING, M. Introdução à qualidade das águas e o tratamento de esgotos. DESA - UFMG, 1996. Available in: http:// www.etg.ufmg.br/tim1/eutrofiz.doc. Accessed at: August 9, 2005.

WESTERMAN, P.W.; DONNELY, T.L.; OVERCASH, M.R. Erosion of soil and poultry manure - a laboratory study. Transactions of the ASAE, v.26, p.1070-1078, 1084, 1983.

WITHERS, P.J.A.; LORD, E.I. Agricultural nutrient inputs to rivers and groundwaters in the UK: Policy, environmental management and research needs. Science of the Total Environment, v.282, p.9-24, 2002.

WITHERS, P.J.A.; DAVIDSON, I.A.; FOY R.H. Prospects for controlling diffuse phosphorus loss to water. Journal of Environmental Quality, v.29, p.167-175, 2000.

Received August 15,2005

Accepted March 15, 2006 